\title{
N(4)-tolyl-2-benzoylpyridine Thiosemicarbazones and their Copper(II) Complexes with Significant Antifungal Activity. Crystal Structure of N(4)-para-tolyl-2-benzoylpyridine Thiosemicarbazone
}

\author{
Isolda C. Mendes, ${ }^{a}$ Juliana P. Moreira, ${ }^{a}$ Nivaldo L. Speziali, ${ }^{b}$ Antonio S. Mangrich, ${ }^{c}$ \\ Jacqueline A. Takahashi ${ }^{a}$ and Heloisa Beraldo ${ }^{*, a}$ \\ ${ }^{a}$ Departamento de Química and ${ }^{b}$ Departamento de Física, Universidade Federal de Minas Gerais, \\ 31270-901 Belo Horizonte - MG, Brazil \\ ${ }^{c}$ Departamento de Química, Universidade Federal do Paraná, 81531-970 Curitiba - PR, Brazil
}

\begin{abstract}
Três complexos inéditos do tipo [Cu(HL)Cl $]$ foram obtidos com N(4)-orto (H2Bz4oT, HL1), N(4)-meta (H2Bz4mT, HL2) e N(4)-para-toluil-2-benzoilpiridina tiossemicarbazona (H2Bz4pT, HL3), nos quais a tiossemicarbazona coordena-se ao metal por meio do sistema quelante $\mathrm{N}_{\mathrm{py}}{ }^{-}$

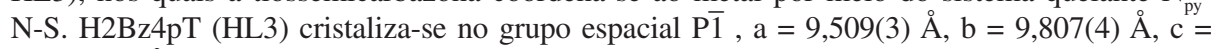
$11,564(4) \AA ; \alpha=100,76(2)^{\circ}, \beta=105,99(2)^{\circ}, \gamma=114,59(2)^{\circ}$. Tanto as tiossemicarbazonas quanto seus complexos de cobre(II) apresentaram atividade antifúngica pronunciada contra Candida albicans, com valores baixos de concentração inibitória mínima (CIM), entre 8 e $0,3 \mu \mathrm{g} \mathrm{mL} \mathrm{m}^{-1}\left(23 \mathrm{a} 0,7 \mu \mathrm{mol} \mathrm{L}^{-1}\right)$ para as tiossemicarbazonas e entre 1 e $0,1 \mu \mathrm{g} \mathrm{mL} \mathrm{m}^{-1}$ ( 2 a $0,3 \mu \mathrm{mol}$ $\left.\mathrm{L}^{-1}\right)$ para os complexos. Nossos resultados sugerem que a coordenação ao cobre constitui estratégia interessante de redução da dose necessária à atividade.
\end{abstract}

Three new copper complexes of general formula $\left[\mathrm{Cu}(\mathrm{HL}) \mathrm{Cl}_{2}\right]$ have been obtained with N(4)-ortho (H2Bz4oT, HL1), N(4)-meta (H2Bz4mT, HL2) and N(4)-para-tolyl-2-benzoylpyridine thiosemicarbazone (H2Bz4pT, HL3), in which the thiosemicarbazone attaches to the metal through the $\mathrm{N}_{-}-\mathrm{N}-\mathrm{S}$ chelating system. H2Bz4pT (HL3) crystallizes in the $\mathrm{P} \overline{1}$ space group, with $\mathrm{a}=9.509(3) \AA \mathrm{Ay}, \mathrm{b}=9.807(4) \AA, \mathrm{c}=11.564(4) \AA ; \alpha=100.76(2)^{\circ}, \beta=105.99(2)^{\circ}, \gamma=114.59(2)^{\circ}$. The thiosemicarbazones and their copper(II) complexes exhibit high antifungal activities against Candida albicans with low values of minimum inhibitory concentration (MIC), in the $8-0.3 \mu \mathrm{g}$ $\mathrm{mL}^{-1}\left(23-0.7 \mu \mathrm{mol} \mathrm{L} \mathrm{L}^{-1}\right)$ range for the free bases and in the $1-0.1 \mu \mathrm{g} \mathrm{mL} \mathrm{L}^{-1}\left(2-0.3 \mu \mathrm{mol} \mathrm{L}^{-1}\right)$ range for the complexes. Our results suggest that coordination to copper(II) could be an interesting strategy for dose reduction.

Keywords: thiosemicarbazones, copper(II) complexes, antifungal activity, Candida albicans

\section{Introduction}

Thiosemicarbazones and their metal complexes present a wide range of bioactivities and their chemistry and pharmacological applications as anticancer, antimicrobial and antiviral agents have been extensively investigated. ${ }^{1,2}$ The biological properties of thiosemicarbazones are often related to metal coordination. ${ }^{3}$

$\alpha(\mathrm{N})$-heterocyclic thiosemicarbazones derived from pyridine have shown to present an interesting pharmacological profile and it has been demonstrated that

*e-mail: hberaldo@ufmg.br the presence of a bulky group at $N(4)$ (see Figure 1) strongly improves their biological activity, ${ }^{3}$ probably due to an increase in lipophilicity.

The antimicrobial activity of 2-formyl- and 2acetylylpyridine-derived thiosemicarbazones was investigated against a variety of bacteria and fungi. ${ }^{1,2}$ The 2-benzoylpyridine analogues have been less studied.

In previous works we started the evaluation of the antimicrobial and cytotoxic activities of 2-benzoylpyridinederived thiosemicarbazones and their metal complexes. $N(4)$-alkyl- and $N(4)$-phenyl-substituted 2-benzoylpyridine thiosemicarbazones have been prepared, as well as their iron(II), palladium(II) and tin(IV) complexes. ${ }^{4-6}$ 
Copper(II) complexes have found possible medical uses in the treatment of many diseases including cancer and microbial infections. ${ }^{7}$ Copper(II) complexes of $N(4)$ substituted 2-benzoylpyridine thiosemicarbazones have been tested against the human pathogenic fungi Aspergillus niger and Paecillomyces variotii. ${ }^{8}$

In the present work we describe the preparation of new copper(II) complexes of N(4)-ortho (H2Bz4oT, hereafter named HL1), N(4)-meta (H2Bz4mT, HL2) and $N(4)$-para-tolyl-2-benzoylpyridine thiosemicarbazone (H2Bz4pT, HL3, Figure 1).

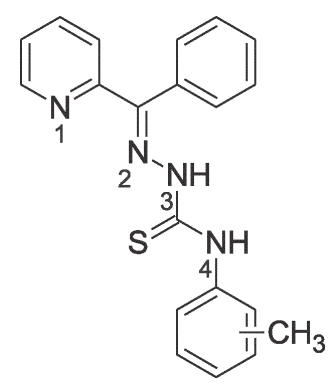

Figure 1. General structure of N(4)-ortho, N(4)-meta and N(4)-para-tolyl2-benzoylpyridine thiosemicarbazones.

The studied compounds have been tested for their antifungal activity against Candida albicans, an opportunistic fungal pathogen leading to systemic or lifethreatening disseminated candidiasis in immunecompromised hosts such as patients with cancer or AIDS. ${ }^{9}$

\section{Experimental}

\section{Apparatus}

Partial elemental analyses were performed on a Perkin Elmer CHN 2400 analyzer. Infrared spectra were recorded on a Perkin Elmer FT-IR Spectrum GX spectrometer using CsI/nujol; an YSI model 31 conductivity bridge was employed for molar conductivity measurements. Magnetic susceptibility measurements were carried out on a Johnson Matthey MSB/AUTO balance. Electron paramagnetic resonance (EPR) spectra were obtained at room temperature $(298 \mathrm{~K})$ on a Bruker ESP300E equipment with modulation frequency of $100 \mathrm{kHz}$ operating at 9.5 $\mathrm{GHz}$ (X-band); solid samples for EPR analyses were firmly accommodated in quartz tubes. X-ray diffraction data were collected on a SIEMENS P4 single-crystal diffractometer.

\section{Synthesis}

The thiosemicarbazones were prepared as described in the literature. ${ }^{10} 2$-benzoylhydrazone was obtained by reacting 2-benzoylpyridine (Aldrich) with a slight excess of hydrazine monohydrate (Aldrich). The thiosemicarbazones were prepared by reacting 2-benzoylpyridine hydrazone with the desired (ortho, meta or para) tolylisothiocyanate (Aldrich). The copper(II) complexes were obtained by refluxing an ethanol solution of the desired thiosemicarbazone with $\mathrm{CuCl}_{2} 2 \mathrm{H}_{2} \mathrm{O}$ (Aldrich) in a 1:1 ligand-to-metal molar ratio. The resulting solids were washed with ethanol followed by diethylether and then dried in vacuo. Crystals of HL3 were obtained by slow diffusion from a 1:9 DMSO/acetone solution and were stable in the air for several hours. Attempts to grow crystals of the complexes in many different solvents were unsuccessful.

Copper(II) complex of 2-benzoylpyridine N(4)-o-tolyl thiosemicarbazone $\left[\mathrm{Cu}(\mathrm{HL} 1) \mathrm{Cl}_{2}\right]$ (1). Brown solid; Anal. Calc. $\left(\mathrm{CuC}_{20} \mathrm{H}_{16} \mathrm{~N}_{4} \mathrm{SCl}_{2}\right)$ : C, 49.95; H, 3.77; N, 11.65 . Found: C, 50.22; H, 3.73; N,11.72\%; FW: $480.90 \mathrm{~g} \mathrm{~mol}^{-1}$. $\mathrm{UV}_{\text {solution }}, \quad \lambda_{\max } / \mathrm{cm}^{-1}: \quad 32362(4.22), \quad 27397(4.14)$, 23474(4.38), 16129(2.41). $\mathrm{UV}_{\text {solid }}, \lambda_{\max } / \mathrm{cm}^{-1}: 31867$, 27770, 23277, 21538, and 16660. IR (CsI/nujol) $v_{\max }$ I $\mathrm{cm}^{-1}: v(\mathrm{NH}) 3423, v(\mathrm{C}=\mathrm{N})+\mathrm{v}(\mathrm{C}=\mathrm{C})$ 1599-1530, $v(\mathrm{C}=\mathrm{S})$ 833, $\rho\left(\right.$ py) 643, v(CuN) 445, v(CuS) 351, v( CuN $\left._{\text {py }}\right) 338$, $v(\mathrm{CuCl}) 313$ and 303 . Molar conductivity $\left(1 \times 10^{-3} \mathrm{~mol} \mathrm{~L}^{-1}\right.$ dimethylformamide, DMF): $17 \Omega^{-1} \mathrm{~cm}^{2} \mathrm{~mol}^{-1}$. Effective Magnetic Moment $=1.84(\mathrm{BM})$. Yield $83 \%$.

Copper(II) complex of 2-benzoylpyridine N(4)-m-tolyl thiosemicarbazone [Cu(HL2) $\left.\mathrm{Cl}_{2}\right]$ (2). Green solid; Anal. Calc. $\left(\mathrm{CuC}_{20} \mathrm{H}_{16} \mathrm{~N}_{4} \mathrm{SCl}_{2}\right)$ : C, 49.95; H, 3.77; N, 11.65. Found: C, 50.31; H, 3.80; N, 11.89\%; FW: $480.90 \mathrm{~g} \mathrm{~mol}^{-1}$. $\mathrm{UV}_{\text {solution }}, \lambda_{\max } / \mathrm{cm}^{-1}: 32205(3.88), 25974(\mathrm{sh}), 23474(4.09)$, $16447(2.43) . \mathrm{UV}_{\text {solid }}, \lambda_{\max } / \mathrm{cm}^{-1}: 31867,27189,23277$, 21993, 16340. IR (CsI/nujol) $v_{\max } / \mathrm{cm}^{-1}: v(\mathrm{NH}) 3306$, $v(\mathrm{C}=\mathrm{N})+v(\mathrm{C}=\mathrm{C})$ 1608-1544, $v(\mathrm{C}=\mathrm{S}) 831, \rho($ py) 642, $v(\mathrm{CuN}) 446, v(\mathrm{CuS}) 350, v\left(\mathrm{CuN}_{\mathrm{py}}\right) 334, v(\mathrm{CuCl}) 318$ and 307. Molar conductivity $\left(1 \times 10^{-3} \mathrm{~mol} \mathrm{~L}^{-1} \mathrm{DMF}\right): 19 \Omega^{-1}$ $\mathrm{cm}^{2} \mathrm{~mol}^{-1}$. Effective Magnetic Moment $=1.82(\mathrm{BM})$. Yield $85 \%$.

Copper(II) complex of 2-benzoylpyridine N(4)-p-tolyl thiosemicarbazone $\left[\mathrm{Cu}\left(\mathrm{HL}_{3}\right) \mathrm{Cl}_{2}\right]$ (3). Brown solid; Anal. Calc. $\left(\mathrm{CuC}_{20} \mathrm{H}_{16} \mathrm{~N}_{4} \mathrm{SCl}_{2}\right): \mathrm{C}, 49.95 ; \mathrm{H}, 3.77 ; \mathrm{N}, 11.65$. Found: $\mathrm{C}, 49.98 ; \mathrm{H}, 3.78 ; \mathrm{N}, 11.59 \%$; FW: $480.90 \mathrm{~g} \mathrm{~mol}^{-1}$. $\mathrm{UV}_{\text {solution, }}$, $\lambda_{\max } / \mathrm{cm}^{-1}:$ 31447(4.11), 26316(sh), 23310(4.28), 16340(2.). $\mathrm{UV}_{\text {solid }} \lambda_{\max } / \mathrm{cm}^{-1}: 31476,26903,22472,20678$, and 16670. IR (CsI/nujol) $v_{\max } / \mathrm{cm}^{-1}: v(\mathrm{NH}) 3318, v(\mathrm{C}=\mathrm{N})+v(\mathrm{C}=\mathrm{C})$ $1610-1533, v(\mathrm{C}=\mathrm{S})$ 836, $\rho$ (py) 630, $v(\mathrm{CuN}) 426, v(\mathrm{CuS})$ $349, v\left(\mathrm{CuN}_{\mathrm{py}}\right) 344, v(\mathrm{CuCl}) 321$ and 318. Molar conductivity $\left(1 \times 10^{-3} \mathrm{~mol} \mathrm{~L}^{-1} \mathrm{DMF}\right): 10 \Omega^{-1} \mathrm{~cm}^{2} \mathrm{~mol}^{-1}$. Effective Magnetic Moment $=1.98(\mathrm{BM})$. Yield $81 \%$. 
Table 1. Crystal data and structure refinement for N(4)-para-tolyl-2-benzoylpyridine thiosemicarbazone (HL3)

\begin{tabular}{ll}
\hline Empirical formula & $\mathrm{C}_{20} \mathrm{H}_{18} \mathrm{~N}_{4} \mathrm{~S}$ \\
Crystal size & $0.10 \times 0.40 \times 0.25 \mathrm{~mm}$ \\
Formula weight & $346.44 \mathrm{~g} \mathrm{~mol}^{-1}$ \\
Temperature & $293(2) \mathrm{K}$ \\
Wavelength & $0.71073 \AA$ \\
Crystal system, space group & Triclinic, $\mathrm{P} 1$ \\
Unit cell dimensions & $\mathrm{a}=9.509(3) \AA, \mathrm{b}=9.807(4) \AA, \mathrm{c}=11.564(4) \AA$ \\
& $\alpha=100.76(2)^{\circ}, \beta=105.99(2)^{\circ}, \gamma=114.59(2)^{\circ}{ }^{\circ}$ \\
Volume & $884.9(5) \AA^{3}$ \\
$Z$, Calculated density & $2,1.300 \mathrm{~g} \mathrm{~cm}^{-3}$ \\
F(000) & 364 \\
$\mu$ & $0.192 \mathrm{~mm}^{-1}$ \\
$\theta$ range for data collection & $1.95-25.00{ }^{\circ}$ \\
Limiting indices & $0 \leq \mathrm{h} \geq 11,-10 \leq \mathrm{k} \geq 9,-13 \leq 1 \geq 13$ \\
Reflections collected / unique & $3175 / 2978[\mathrm{R}(\mathrm{int})=0.0240]$ \\
Observed reflections & $1786(\mathrm{I} \geq 2 \sigma(\mathrm{I}))$ \\
Completeness to $\theta=25.00$ & $95.6 \%$ \\
Absorption correction & $\mathrm{None}$ \\
Data / restraints / parameters & $2978 / 0 / 226$ \\
Final R indices [I $2 \sigma(\mathrm{I})]$ & $\mathrm{R} 1=0.0573, \mathrm{wR} 2=0.1437$ \\
$\mathrm{R}$ indices (all data) & $\mathrm{R} 1=0.0761, \mathrm{wR} 2=0.1576$ \\
Goodness-of-fit on $\mathrm{F}^{2}$ & 1.043 \\
Largest diff. peak and hole & $-0.321 / 0.377 \mathrm{e} \AA^{-3}$ \\
\hline
\end{tabular}

\section{Crystal structure determination}

The crystal structure of HL3 was investigated using single-crystal X-ray diffractometry. Data have been collected on a P4-SIEMENS diffractometer, using Mo- $\mathrm{K}_{\alpha}$ monochromated radiation in the $\theta-2 \theta$ mode. Lattice parameters were obtained by least-square fit from 34 reflections, with $5<\theta<13$. Crystal data, data collection procedure, structure determination methods and refinement results are summarized in Table 1. The hydrogen atoms were positioned on stereochemical basis.

Programs and methods used in the X-ray diffraction experiments and structural analysis are detailed in references. ${ }^{11-13}$

\section{Antifungal activity}

Antifungal activity was evaluated by minimum inhibitory concentration (MIC) using the macro dilution test. ${ }^{14,15}$ Candida albicans, stored in Sabouraud broth, was subcultured for testing in the same medium and grown at $37{ }^{\circ} \mathrm{C}$. Then the yeast cells were suspended, according to the McFarland protocol, in saline solution, to produce a suspension of about $10^{-5} \mathrm{CFU} \mathrm{mL} \mathrm{mL}^{-1}$ (colony-forming units per $\mathrm{mL}$ ). Serial dilutions of the test compounds, previously dissolved in dimethyl sulfoxide (DMSO), were prepared in test tubes to final concentrations of $512,256,128,64,32,16,8,4,2,1,0.5$, 0.3 and $0.1 \mu \mathrm{g} \mathrm{mL}-100 \mu \mathrm{L}$ of a $24 \mathrm{~h}$ old inoculum was added to each tube. The MIC, defined as the lowest concentration of the test compound, which inhibits the visible growth after $18 \mathrm{~h}$, was determined visually after incubation for $18 \mathrm{~h}$ at $37^{\circ} \mathrm{C}$. Tests using DMSO as negative control were carried out in parallel. All tests were performed in duplicate with full agreement between results.

\section{Results and Discussion}

Structural analysis of N(4)-para-tolyl-2-benzoylpyridine thiosemicarbazone (HL3)

The crystal structure of N(4)-para-tolyl-2benzoylpyridine thiosemicarbazone ( HL3) was refined in the $\mathrm{P} \overline{1}$ space group with one molecule in the asymmetric unit $(Z=2)$. Selected intramolecular bond distances and angles are given in Table 2; hydrogen bond distances and angles are detailed in Table 3 and the asymmetric unit is shown in perspective in Figure 2. As expected, the bond distances in HL3 (N(4)-para tolyl-2benzoylpyridine thiosemicarbazone, see Table 2) are very similar to those determined previously for $N(4)$-phenyl2-benzoylpyridine thiosemicarbazone $(\mathrm{H} 2 \mathrm{Bz} 4 \mathrm{Ph}){ }^{5}$ Small differences were observed in the $\mathrm{S}(1)-\mathrm{C}(8)$ and $\mathrm{N}(2)-\mathrm{N}(3)$ bond distances, which are 1.650(2) and 1.351(3) $\AA$ for HL3 and 1.663(2) and 1.362(2) $\AA$ for $\mathrm{H} 2 \mathrm{Bz} 4 \mathrm{Ph}$, and in the $\mathrm{N}(4)-\mathrm{C}(8)-\mathrm{N}(3)$ bond angle, which is 113.5(2) for HL3 and 114.3(2) ${ }^{\circ}$ for H2Bz4Ph. Also, the $\mathrm{C}(7)-\mathrm{N}(2)-\mathrm{N}(3)$ bond angle is 120.6(2) for HL3 and 119.4(2) ${ }^{\circ}$ for $\mathrm{H} 2 \mathrm{Bz} 4 \mathrm{Ph}$.

The angles between the plane of the thiosemicarbazone moiety and the plane of the pyridine ring 


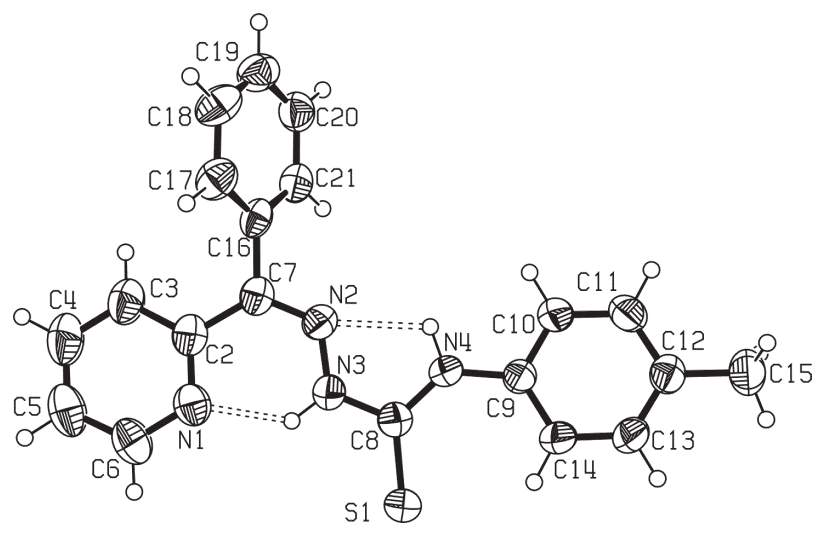

Figure 2. Molecular plot of HL3 showing the labeling scheme of the non- $\mathrm{H}$ atoms and their displacement ellipsoids at the $50 \%$ probability level.

Table 2. Selected bond distances and angles for N(4)-para-tolyl-2benzoylpyridine thiosemicarbazone (HL3)

\begin{tabular}{lclc}
\hline Atoms & Distance / & Atoms & Angle / ( $\left.{ }^{\circ}\right)$ \\
\hline $\mathrm{S}(1)-\mathrm{C}(8)$ & $1.650(2)$ & $\mathrm{N}(2)-\mathrm{N}(3)-\mathrm{C}(8)$ & $120.5(2)$ \\
$\mathrm{N}(2)-\mathrm{C}(7)$ & $1.293(3)$ & $\mathrm{N}(3)-\mathrm{C}(8)-\mathrm{S}(1)$ & $117.9(2)$ \\
$\mathrm{N}(2)-\mathrm{N}(3)$ & $1.351(3)$ & $\mathrm{N}(4)-\mathrm{C}(8)-\mathrm{N}(3)$ & $113.5(2)$ \\
$\mathrm{N}(3)-\mathrm{C}(8)$ & $1.360(3)$ & $\mathrm{N}(4)-\mathrm{C}(8)-\mathrm{S}(1)$ & $128.6(2)$ \\
$\mathrm{N}(4)-\mathrm{C}(8)$ & $1.342(3)$ & $\mathrm{C}(7)-\mathrm{N}(2)-\mathrm{N}(3)$ & $120.6(2)$ \\
$\mathrm{N}(4)-\mathrm{C}(9)$ & $1.404(3)$ & $\mathrm{C}(8)-\mathrm{N}(4)-\mathrm{C}(9)$ & $132.3(2)$ \\
\hline
\end{tabular}

are quite similar in the two compounds i.e. $10.0^{\circ}$ and $10.6^{\circ}$ in HL3 and $\mathrm{H} 2 \mathrm{Bz} 4 \mathrm{Ph}$ respectively. However, the angle between the plane of the phenyl ring attached to C7 and the plane of the lateral chain is different for the two thiosemicarbazones i.e. $52.3^{\circ}$ and $60.13^{\circ}$ for HL3 and $\mathrm{H} 2 \mathrm{Bz} 4 \mathrm{Ph}$ respectively. The angle between the thiosemicarbazone chain and the N(4)-phenyl ring for HL3 is smaller $\left(11.0^{\circ}\right)$ than the corresponding angle in $\mathrm{H} 2 \mathrm{Bz} 4 \mathrm{Ph}\left(16.0^{\circ}\right)$. These differences in the angles allow shorter intermolecular distances, e.g., N(4)...N(3)_2 and N(4)...N(4)_2 which are 3.503 and $3.438 \AA$ in HL3, and 3.717 and $3.554 \AA$ in $\mathrm{H} 2 \mathrm{Bz} 4 \mathrm{Ph} .{ }^{5,16}$ Nevertheless, the molecular packing is almost the same in both compounds (the density values are 1.300 and $1.287 \mathrm{~g}$ $\mathrm{cm}^{-3}$ respectively).

Both HL3 and $\mathrm{H} 2 \mathrm{Bz} 4 \mathrm{Ph}$ crystallize in the $Z E$ configuration in relation to the $\mathrm{C}(7)-\mathrm{N}(2)$ and $\mathrm{N}(3)$ $\mathrm{C}(8)$ bonds respectively. This configuration is stabilized by a hydrogen bond between $\mathrm{N} 3-\mathrm{H}$ and the heteroaromatic nitrogen. ${ }^{5}$ The signals in the ${ }^{1} \mathrm{H}$ and ${ }^{13} \mathrm{C}$ NMR spectra (DMSO- $d_{6}$ ) of both compounds (Tables S1 and S2, Supplementary Information) are duplicated, indicating the presence of the $Z$ and $E$ isomers in solution. The signal at $\delta=13.03 \mathrm{ppm}$ for HL3 and at $\delta=13.14 \mathrm{ppm}$ for $\mathrm{H} 2 \mathrm{Bz} 4 \mathrm{Ph}^{5}$ are characteristic of
Table 3. Hydrogen bond parameters for N(4)-para-tolyl-2-benzoylpyridine thiosemicarbazone (HL3). $\mathrm{H} \cdots \mathrm{A}<\mathrm{r}(\mathrm{A})+2.00 \AA$ and $<\mathrm{DHA}>110^{\circ}$

\begin{tabular}{lcccc}
\hline $\mathrm{D}-\mathrm{H} \cdots \mathrm{A}$ & $\mathrm{D}-\mathrm{H} / \AA$ & $\mathrm{H} \cdots \mathrm{A} / \AA$ & $\mathrm{D} \cdots \mathrm{A} / \AA$ & $\mathrm{D}-\mathrm{H} \cdots \mathrm{A} /\left(^{\circ}\right)$ \\
\hline $\mathrm{N}(3)-\mathrm{H} \cdots \mathrm{N}(1)$ & 0.9 & 1.93 & $2.615(3)$ & 132 \\
$\mathrm{~N}(4)-\mathrm{H} \cdots \mathrm{N}(2)$ & 0.9 & 2.11 & $2.579(3)$ & 112 \\
\hline
\end{tabular}

$\mathrm{N}(3)-\mathrm{H}$ hydrogen bonded to the pyridine nitrogen in the $Z$ configuration, whereas those at $\delta=10.48 \mathrm{ppm}$ for HL3 and at $\delta=10.63 \mathrm{ppm}$ for $\mathrm{H} 2 \mathrm{Bz} 4 \mathrm{Ph}^{5}$ are characteristic of $\mathrm{N}(3)-\mathrm{H}$ hydrogen bonded to DMSO ( $E$ configuration). ${ }^{5,6,17}$ The $Z$ form is predominant in solution (70\%) for both compounds.

Intramolecular $\mathrm{N}(4)-\mathrm{H} \ldots \mathrm{N}(2)$ and $\mathrm{N}(3)-\mathrm{H} \ldots \mathrm{N}(1)$ hydrogen bonds characteristic of the $Z E$ configuration are formed in both HL3 (see Table 3) and H2Bz4Ph.

Microanalyses suggest the formation of $\left[\mathrm{Cu}(\mathrm{HL}) \mathrm{Cl}_{2}\right]$ in all cases. The molar conductivity data indicate that all complexes are non-electrolytes, ${ }^{18}$ in accordance with the proposed formulations. The effective magnetic moments in the 1.82-1.98 BM range are close to the calculated spinonly value of $1.73 \mathrm{BM}$ for one unpaired electron, as expected for copper(II) complexes.

\section{Infrared Spectra}

The $v(\mathrm{C}=\mathrm{C})+v(\mathrm{C}=\mathrm{N})$ composed mode observed in the $1600-1560 \mathrm{~cm}^{-1}$ range in the spectra of the free bases shifts to $1610-1530 \mathrm{~cm}^{-1}$ in the spectra of the complexes, indicating coordination of the azomethine nitrogen $\mathrm{N}(2){ }^{4-6}$

The $v(C=S)$ absorption at $849-846 \mathrm{~cm}^{-1}$ in the spectra of the uncomplexed thiosemicarbazones is observed at $836-831 \mathrm{~cm}^{-1}$ in those of the complexes, in accordance with coordination through the sulfur. The $13-15 \mathrm{~cm}^{-1}$ shift observed upon complexation is compatible with coordination of a neutral thiosemicarbazone in all cases. ${ }^{6}$ The pyridine in-plane deformation mode at 615 $613 \mathrm{~cm}^{-1}$ in the spectra of the free thiosemicarbazones shifts to $643-630 \mathrm{~cm}^{-1}$ in those of the complexes, suggesting coordination of the heteroaromatic nitrogen. . $^{4}$

In addition, new absorptions at $446-426 \mathrm{~cm}^{-1}$ and 344$334 \mathrm{~cm}^{-1}$ have been attributed to $v(\mathrm{Cu}-\mathrm{N})$ and $v\left(\mathrm{Cu}-\mathrm{N}_{\mathrm{py}}\right)$, respectively and bands in the $351-349 \mathrm{~cm}^{-1}$ range have been assigned to $\mathrm{v}(\mathrm{Cu}-\mathrm{S})$. Two bands at $321-303 \mathrm{~cm}^{-1}$ were attributed to $\mathrm{v}(\mathrm{Cu}-\mathrm{Cl}) .{ }^{19}$ This splitting is characteristic of the presence of two chlorides in cis position to each other. ${ }^{6}$

The infrared data for the three complexes indicate coordination of the thiosemicarbazones through the $\mathrm{N}_{\mathrm{py}}-\mathrm{N}-\mathrm{S}$ chelating system. 


\section{Electronic Spectra}

In the electronic spectra of the thiosemicarbazones (DMSO) the $\pi-\pi^{*}$ absorptions at $c a .37000 \mathrm{~cm}^{-1}$ are not significantly modified upon complexation. The absorption at $31746-29673 \mathrm{~cm}^{-1}$ was attributed to $\mathrm{n}-\pi^{*}$ transitions associated to the pyridine ring and to the azomethine and thioamide functions $\mathrm{s}^{4-6}$ which overlap under the same envelope. In the spectra of complexes (1)-(3) three absorptions were observed in the 32362-31447, 27397 25974 and $23474-23310 \mathrm{~cm}^{-1}$ ranges. The first two were assigned to $n-\pi^{*}$ transitions of the pyridine and to the azomethine and thioamide functions, and the latter to $\mathrm{N}$ $\mathrm{Cu}^{\mathrm{II}}$ and $\mathrm{S}-\mathrm{Cu}^{\mathrm{II}}$ ligand-to-metal charge transfer transitions. ${ }^{19} \mathrm{~d}-\mathrm{d}$ transitions were found at 16447-16129 $\mathrm{cm}^{-1} .{ }^{19}$ The electronic spectra of the solids are not significantly different, particularly in the d-d region.

\section{EPR Spectra}

Table 4 presents the attributed d-d transitions, the EPR $\mathrm{g}$ values and the magnetic moments for the three studied complexes. The relatively low $g$ values of the complexes are characteristic of an $\mathrm{N}$-rich environment around the $\mathrm{Cu}^{2+}$ ions. ${ }^{20}$ The very low parallel component of the hyperfine coupling constant (not resolved in the spectra) has been explained by considering a mixture of the $d_{z}^{2}$ with $d_{x}{ }^{2}-{ }_{y}^{2}$ as the ground state. It is found that a $10 \%$ mixture of $d_{x}^{2}-y_{y}^{2}$ and $d_{z}^{2}$ results in a $20 \%$ reduction in dipolar anisotropy. The magnetic moments calculated from the EPR $g_{a v}$ values are in reasonable agreement with the measured values..$^{21,22}$

The foregoing results, along with the infrared data, strongly suggest a square pyramidal arrangement for the complexes, in which the metal centre is surrounded by the thiosemicarbazones' $\mathrm{N}_{\mathrm{py}}-\mathrm{N}-\mathrm{S}$ chelating system and a chloride ion in the pyramid base. The apical position is occupied by a second chloride ion.

\section{Antifungal activity}

Table 5 lists the minimum inhibitory concentration (MIC) of the thiosemicarbazones and their copper(II)

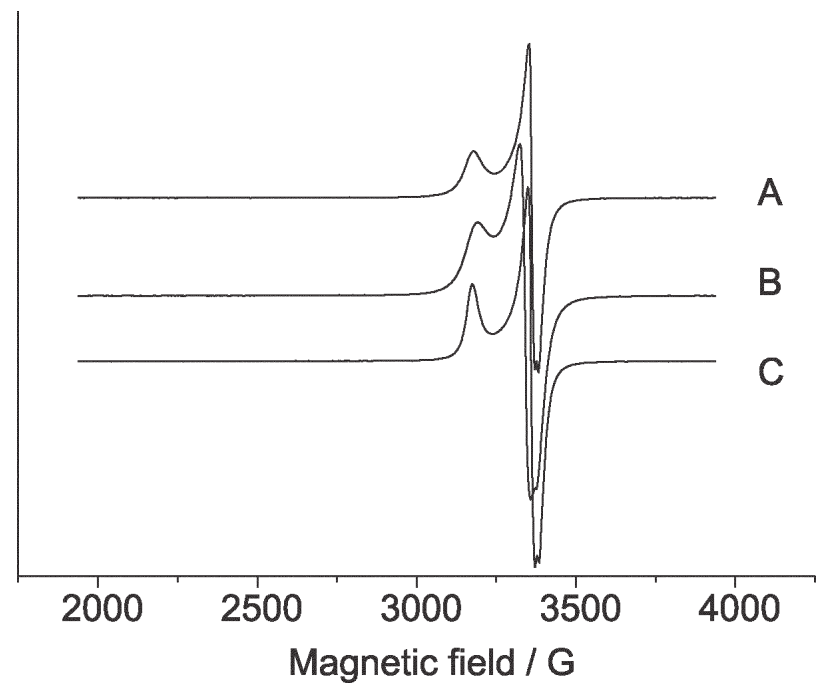

Figure 3. X-band EPR spectra of (A) $\left[\mathrm{Cu}(\mathrm{HL} 1) \mathrm{Cl}_{2}\right](\mathbf{1})$; (B) $\left[\mathrm{Cu}(\mathrm{HL} 2) \mathrm{Cl}_{2}\right]$ (2); (C) $\left[\mathrm{Cu}(\mathrm{HL} 3) \mathrm{Cl}_{2}\right](\mathbf{3})$ at room temperature $(\sim 300 \mathrm{~K})$.

complexes against the growth of Candida albicans. For the three thiosemicarbazones we found that MIC is lower than $8 \mu \mathrm{g} \mathrm{mL}^{-1}\left(23 \mu \mathrm{mol} \mathrm{L}^{-1}\right)$ and for the complexes we found values of MIC in the 1-0.1 $\mu \mathrm{g} \mathrm{mL}^{-1}\left(2-0.3 \mu \mathrm{mol} \mathrm{L}^{-1}\right)$ range. These values are low as compared with those reported in the literature for clinically used drugs such as amphotericin B, with reported MICs in the $2-25 \mu \mathrm{g} \mathrm{mL}^{-1}$ range. ${ }^{15,23}$ Other thiosemicarbazones presented MIC in the 25-200 $\mu \mathrm{g} \mathrm{mL}^{-1}$ range. ${ }^{23}$ Taking into consideration that the molecular weight of the complexes is 1.4 times that of the free thiosemicarbazones, we may assume that the antifungal activity is significantly enhanced upon coordination to copper(II).

The differences in activity between the three thiosemicarbazones could be due to the hyperconjugation effect of the tolyl methyl group that favors concentration of negative charge at $\mathrm{C}(9)$ in the ortho and para derivatives..$^{24,25}$ In this case the non-bonding electron pair at $\mathrm{N}(4)$ cannot be involved in resonance with the tolyl ring and participates in delocalization only along the thiosemicarbazone chain. In the meta derivative hyperconjugation does not favor concentration of negative charge at $C(9)$. Therefore resonance involving the non-bonding electron pair at

Table 4. Ligand field transitions in the electronic spectrum (solid state), room temperature EPR parameters and calculated magnetic moments for the copper(II) complexes of N(4)-tolyl-2-benzoylpyridine thiosemicarbazones

\begin{tabular}{lcccccc}
\hline Complex & $\mathrm{d}-\mathrm{d} / \mathrm{cm}^{-1}$ & $\mathrm{~g}_{1}$ & $\mathrm{~g}_{2}$ & $\mathrm{~g}_{3}$ & $\mathrm{~g}_{\mathrm{av}}$ & $\mu_{\text {cal }} / \mathrm{BM}$ \\
\hline$\left[\mathrm{Cu}(\mathrm{HL} 1) \mathrm{Cl}_{2}\right](\mathbf{1})$ & 16660 & 2.156 & - & 2.036 & 2.096 & 1.82 \\
{$\left[\mathrm{Cu}(\mathrm{HL} 2) \mathrm{Cl}_{2}\right](\mathbf{2})$} & 16340 & 2.147 & 2.055 & 2.041 & 2.081 & 1.80 \\
{$\left[\mathrm{Cu}(\mathrm{HL} 3) \mathrm{Cl}_{2}\right](\mathbf{3})$} & 16670 & 2.136 & 2.056 & 2.033 & 2.082 & 1.80 \\
\hline
\end{tabular}


Table 5. Minimum Inhibitory Concentration (MIC) against Candida albicans (ATCC18804) for N(4)-tolyl thiosemicarbazones and their copper(II) complexes

\begin{tabular}{|c|c|c|c|c|c|}
\hline \multirow[t]{2}{*}{ Compound } & \multicolumn{2}{|c|}{ MIC / } & \multirow[t]{2}{*}{ Compound } & \multicolumn{2}{|c|}{ MIC / } \\
\hline & $\left(\mu \mathrm{g} \mathrm{mL}^{-1}\right)$ & $(\mu \mathrm{mol} \mathrm{L}-1)$ & & $\left(\mu \mathrm{g} \mathrm{mL} L^{-1}\right)$ & $(\mu \mathrm{mol} \mathrm{L}-1)$ \\
\hline HL1 & 2 & 6 & {$\left[\mathrm{Cu}(\mathrm{HL} 1) \mathrm{Cl}_{2}\right](\mathbf{1})$} & 1 & 2 \\
\hline HL2 & 8 & 23 & {$\left[\mathrm{Cu}(\mathrm{HL} 2) \mathrm{Cl}_{2}\right](2)$} & 0.3 & 0.5 \\
\hline HL3 & 0.3 & 0.7 & {$\left[\mathrm{Cu}(\mathrm{HL} 3) \mathrm{Cl}_{2}\right](\mathbf{3})$} & 0.1 & 0.3 \\
\hline- & - & - & $\mathrm{CuCl}_{2} 2 \mathrm{H}_{2} \mathrm{O}$ & 64 & 375 \\
\hline
\end{tabular}

$\mathrm{N}(4)$ and the tolyl ring occurs, as well as resonance within the thiosemicarbazone chain. The much lower activity of the meta derivative suggests that resonance involving $\mathrm{N}(4)$ and the tolyl ring disfavors the antifungal action. Comparison between the ortho and para derivatives suggests that the lower activity of the ortho derivative could possibly be related to sterical hindrance of the ortho methyl group.

The higher activity of the complexes could be due to modifications of lipophilicity. Also, since the copper salt exhibited antifungal activity with MIC $=64 \mu \mathrm{g} \mathrm{mL}^{-1}$, a synergistic effect of both thiosemicarbazone and metal acting together could take place. Moreover, upon complexation, the thiosemicarbazones adopt the $E Z$ configuration, which seems to facilitate their interaction with the biological target.

Upon coordination $\pi$-back donation from the copper to the sulfur occurs, with simultaneous $\sigma$-donation from the sulfur to the metal. This effect favors resonance involving $\mathrm{N}(4)-\mathrm{C}(8)$-S to occur preferentially over resonance with the tolyl ring, which could explain the significant improvement of activity in complex (2) containing the meta derivative.

The foregoing results suggest that pharmaceutical formulations using the copper complexes could constitute an interesting strategy for dose reduction. Furthermore, preparation of new antifungal agents is extremely important considering the widespread occurrence of cell resistance to clinically used drugs.

\section{Acknowledgments}

This work was supported by CNPq and Instituto do Milênio - Inovação e Desenvolvimento de Novos Fármacos e Medicamentos (IM-INOFAR) (Proc. CNPq 420015/05-1).

\section{Supplementary Information}

Crystallographic Data for H2Bz4pT (HL3) have been deposited at the Cambridge Crystallographic Data Centre as supplementary publication number CCDC 610054 . Copies of available material can be obtained on application to CCDC, 12, Union Road, Cambridge CB2 IEZ, UK (fax 44-1223-336033 or e-mail:deposit@ccdc.cam.ac.uk).

Tables of ${ }^{1} \mathrm{H}$ and ${ }^{13} \mathrm{C}$ chemical shift data and assignments for HL3 are available free of charge at http://jbcs.sbq.org.br.

\section{References}

1. Beraldo, H.; Gambino, D.; Mini-Rev. Med. Chem. 2004, 4, 31 and references therein.

2. Beraldo, H.; Quim. Nova 2004, 27, 461 and references therein.

3. West, D. X.; Liberta, A.; Padhye, S. B.; Chikate, R. C.; Sonawana, P. B.; Kumbhar, A. S.; Yerande, R. G.; Coord. Chem. Rev. 1993, 123, 49; West, D. X.; Padhye, S. B.; Sonawana, P. B.; Struct. Bond. 1991, 76, 1.

4. Rebolledo, A. P.; Vieites, M.; Gambino, D.; Piro, O. E.; Castellano, E. E.; Zani, C. L.; Souza-Fagundes, E. M.; Teixeira, L. R.; Batista, A. A.; Beraldo, H.; J. Inorg. Biochem. 2005, 99, 698.

5. Rebolledo, A. P.; De Lima, G. M.; Gambi, L. N.; Speziali, N. L.; Maia, D. F.; Pinheiro, C. B.; Ardisson, J. D.; Cortés, M. E.; Beraldo, H.; Appl. Organomet. Chem. 2003, 17, 945.

6. Costa, R. F. F.; Rebolledo, A. P.; Matencio, T.; Calado, H. D. R.; Ardisson, J. D.; Cortès, M. E.; Rodrigues, B. L.; Beraldo, H.; J. Coord. Chem. 2005, 58, 1307.

7. Halova-Lajoie, B.; Brumas, V.; Fiallo, M. L.; Berthon, G.; J. Inorg. Biochem. 2006, 100, 362.

8. West, D. X.; Ives, J. S.; Krejci, J.; Salberg, M.; Zumbahlen, T. L.; Bain, G.; Liberta, A.; Martinez, J. V.; Ortiz, S. H.; Toscano, R.; Polyhedron 1995, 14, 2189.

9. Coleman, D. C.; Bennett, D. E.; Sullivan, D. J.; Gallagher, P. J.; Henman, M. C.; Stanley, D. B and Russel R. J.; Crit. Rev. Microbiol. 1993, 19, 61.

10. Miller, M. C.; Stineman, C. N.; Vance, J. R.; West, D. X.; Hall, I. H.; Anticancer Res. 1998, 18, 4131.

11. Farrugia L. J.; J. Appl. Cryst. 1997, 30, 565; Farrugia L. J.; J. Appl. Cryst. 1999, 32, 837.

12. Sheldrick, G. M.; SHELXS-97 Program for the Solution of Crystal Structures; University of Göttingen: Germany, 1997.

13. Sheldrick, G. M.; SHELXL-97 Program for Crystal Structures Analysis; University of Göttingen: Germany, 1997.

14. Lana, E. J. L.; Carazza, F.; Takahashi, J. A.; J. Agric. Food Chem. 2006, 54, 2053. 
15. Resende, J. C. P.; Resende, M. A.; Mycoses 1999, 42, 641.

16. Pérez-Rebolledo, A.; Ayala, J. D.; De Lima, G. M.; Marchini, N.; Bombieri, G.; Zani, C. L.; Souza-Fagundes, E. M.; Beraldo, H.; Eur. J. Med. Chem. 2005, 40, 467.

17. West, D. X.; Billeh, I. S.; Jasinski, J. P.; Jasinski, J. M.; Butcher, R. J.; Transition Met. Chem. 1998, 23, 209.

18. Geary, W. J.; Coord. Chem. Rev. 1971, 7, 81.

19. Joseph, M.; Kuriakose, M.; Kurup, P.; Suresh, E.; Kishore, A.; Bhat, S. G.; Polyhedron 2006, 25, 61.

20. Guimarães, E.; Mangrich, A. S.; Machado, V. G.; Traghetta, D. G.; Lobo, M. A.; J. Braz. Chem. Soc. 2001, 12, 734.

21. Koulougliotis, D.; Schweitzer, R. H.; Brudvig, G. W.; Biochemistry 1997, 36, 9735.
22. Huang, H.; Sakurai, T.; Maritano, S.; Marchesini, A.; Suzuki, S.; J. Inorg. Biochem. 1999, 75, 19.

23. Balasubramanian, S.; Ramalingan, C.; Aridoss G.; Kabilan S.; Eur. J. Med. Chem. 2005, 40, 694.

24. McMurry, J.; Organic Chemistry, $2^{\text {nd }}$ ed., Brook/Cole: Pacific Grove, 1988.

25. March, J.; Advanced Organic Chemistry, $2^{\text {nd }}$ ed., McGraw Hill: Tokyo, 1977.

Received: June 8, 2006 Published on the web: November 14, 2006 


\title{
N(4)-Tolyl-2-benzoylpyridine Thiosemicarbazones and their Copper(II) Complexes with Significant Antifungal Activity. Crystal Structure of N(4)-Para-tolyl-2-benzoylpyridine Thiosemicarbazone
}

\author{
Isolda C. Mendes, ${ }^{a}$ Juliana P. Moreira, ${ }^{a}$ Nivaldo L. Speziali, ${ }^{b}$ Antonio S. Mangrich, ${ }^{c}$ \\ Jacqueline A. Takahashi ${ }^{a}$ and Heloisa Beraldo ${ }^{*, a}$ \\ ${ }^{a}$ Departamento de Química, ${ }^{b}$ Departamento de Física, Universidade Federal de Minas Gerais, \\ 31270-901 Belo Horizonte-MG, Brazil \\ ${ }^{c}$ Departamento de Química, Universidade Federal do Paraná, 81531-970 Curitiba-PR , Brazil
}

Table S1. The main ${ }^{1} \mathrm{H}$ NMR signals $(\delta$, ppm) of isomers $Z$ and $E$ for N(4)-para-tolyl-2-benzoylpyridine thiosemicarbazone (HL3) in DMSO- $d$

\begin{tabular}{|c|c|c|c|c|}
\hline \multirow[t]{2}{*}{ Attribution } & \multicolumn{2}{|c|}{ HL3 } & \multicolumn{2}{|c|}{ Multiplicity } \\
\hline & $Z$ & $E$ & $Z$ & $E$ \\
\hline $\mathrm{H}(3)$ & $7.48 \quad 7.39$ & 8.678 .65 & $\mathrm{~d}$ & $\mathrm{~d}$ \\
\hline $\mathrm{H}(4)$ & 8.048 .02 & 7.937 .91 & $\mathrm{t}$ & $\mathrm{t}$ \\
\hline $\mathrm{H}(5)$ & 7.637 .61 & 7.607 .56 & $\mathrm{t}$ & $\mathrm{t}$ \\
\hline $\mathrm{H}(6)$ & 8.898 .87 & 8.478 .46 & $\mathrm{~d}$ & $\mathrm{~d}$ \\
\hline $\mathrm{N}(3)-\mathrm{H}$ & 13.03 & 10.48 & $\mathrm{~s}$ & $\mathrm{~s}$ \\
\hline $\mathrm{N}(4)-\mathrm{H}$ & 10.22 & 8.93 & $\mathrm{~s}$ & $\mathrm{~s}$ \\
\hline
\end{tabular}

$\mathrm{s}=$ singlet, $\mathrm{d}=$ doublet and $\mathrm{t}=$ triplet.
Table S2. The main ${ }^{13} \mathrm{C}$ NMR signals $(\delta$, ppm) of isomers $Z$ and $E$ for $N(4)$-para-tolyl-2-benzoylpyridine thiosemicarbazone (HL3) in DMSO- $d_{6}$

\begin{tabular}{lcc}
\hline Attribution & \multicolumn{2}{c}{ HL3 } \\
\cline { 2 - 3 } & \multicolumn{1}{c}{$Z$} \\
\hline $\mathrm{C}(2)$ & 151.40 & 154.37 \\
$\mathrm{C}(3)$ & 125.26 & 122.80 \\
$\mathrm{C}(4)$ & 138.29 & 136.48 \\
$\mathrm{C}(5)$ & 125.26 & 124.12 \\
$\mathrm{C}(6)$ & 148.89 & 148.63 \\
$\mathrm{C}(7)=\mathrm{N}$ & 143.70 & 149.56 \\
$\mathrm{C}(8)=\mathrm{S}$ & 176.52 & 176.34 \\
\hline
\end{tabular}

